\title{
Neuropathology of transgenic HD animal models
}

\author{
Xiaojiang Li ${ }^{*}$, Shihua Li \\ From 2011 International Conference on Molecular Neurodegeneration \\ Shanghai, China. 22-24 September 2011
}

\section{Background}

Identification of the polyglutamine expansion in huntingtin (htt) responsible for Huntington disease (HD) has allowed the establishment of a variety of transgenic mouse models of HD. Although these mouse models have been widely used to uncover the pathogenesis of HD and to develop its treatments, most of these mouse models show no overt neurodegeneration in their brains. Similarly, transgenic mouse models for other neurodegenerative diseases such as Alzheimer's and Parkinson's diseases do not display obvious apoptosis or significant neurodegeneration either.

\section{Methods}

To address the effect of protein context rather than overexpression or ectopic expression of transgenes, we used the gene-targeting approach to generate a knock-in mouse model that expresses $\mathrm{N}$-terminal mutant htt under the control of the endogenous mouse htt promoter. This mouse model also shows the preferential accumulation of mutant htt in the striatum and age-dependent neurological phenotypes, providing the strong evidence for the pathogenic role of $\mathrm{N}$-terminal mutant htt. To compare the effects of different species on HD neuropathology, we generated transgenic pigs and mice that express the same mutant htt.

\section{Results}

Expression of this $\mathrm{N}$-terminal mutant htt leads to more severe neurological phenotypes in transgenic pigs than transgenic mice. Moreover, mutant htt can cause apoptotic cells in the pig brains, but not in the transgenic mouse brains.

\section{Conclusion}

These studies suggest that species differences and protein context of mutant htt determine the nature of neuropathology in HD and underscore the importance of

Department of Human Genetics, Emory University, Atlanta, GA, USA utilizing different transgenic animal models to understand the pathogenesis of HD.

Published: 7 February 2012

doi:10.1186/1750-1326-7-S1-L17

Cite this article as: $\mathrm{Li}$ and $\mathrm{Li}$ : Neuropathology of transgenic HD animal models. Molecular Neurodegeneration 2012 7(Suppl 1):L17.
Submit your next manuscript to BioMed Central and take full advantage of:

- Convenient online submission

- Thorough peer review

- No space constraints or color figure charges

- Immediate publication on acceptance

- Inclusion in PubMed, CAS, Scopus and Google Scholar

- Research which is freely available for redistribution
() Bïomed Central

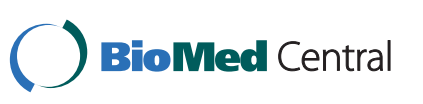

(c) 2012 Li and Li; licensee BioMed Central Ltd. This is an Open Access article distributed under the terms of the Creative Commons Attribution License (http://creativecommons.org/licenses/by/2.0), which permits unrestricted use, distribution, and reproduction in any medium, provided the original work is properly cited. 